\title{
Oxysterols Present in Atherosclerotic Tissue Decrease the Expression of Lipoprotein Lipase Messenger RNA in Human Monocyte-derived Macrophages
}

\author{
Lillemor Mattsson Hultén, ${ }^{*}$ Helena Lindmark, ${ }^{*}$ Ulf Diczfalusy, ${ }^{\ddagger}$ Ingemar Björkhem, ${ }^{\ddagger}$ Malin Ottosson, ${ }^{*}$ Yani Liu, ${ }^{\star}$ \\ Göran Bondjers, ${ }^{\star}$ and Olov Wiklund* \\ *Wallenberg Laboratory for Cardiovascular Research, University of Göteborg, S-413 45 Göteborg; and ${ }^{\ddagger}$ Department of Clinical \\ Chemistry, Huddinge University Hospital, S-14186 Huddinge, Sweden
}

\begin{abstract}
The presence of oxysterols in macrophages isolated from atherosclerotic tissue and the effect of oxysterols on the regulation of lipoprotein lipase (LPL) mRNA were studied. Both rabbit and human macrophages, freshly isolated from atherosclerotic aorta, show about the same distribution of oxysterols, analyzed by isotope dilution mass spectrometry, except that all three preparations of human arterial-derived macrophages contained high levels of 27-hydroxycholesterol, which was not found in rabbit macrophages. To determine if oxysterols regulate LPL expression, human monocyte-derived macrophages were incubated with different oxysterols. Incubation with 7 $\beta$-hydroxycholesterol and 25hydroxycholesterol resulted in a 70-75\% reduction of LPL mRNA, analyzed by quantitative RT-PCR. Cholesterol and other tested oxysterols showed no effect on macrophage LPL mRNA expression compared with control. LPL activity in the medium was also reduced after exposure of the macrophages to $7 \beta$-hydroxycholesterol and 25 -hydroxycholesterol. In conclusion, we have demonstrated accumulation of oxysterols in macrophage-derived foam cells isolated from atherosclerotic aorta. There was suppression of LPL mRNA in human monocyte-derived macrophages after incubation with 7及-hydroxycholesterol and 25-hydroxycholesterol. It is tempting to suggest that an exposure to oxysterols may explain our earlier observation of a low level of LPL mRNA in arterial foam cells. (J. Clin. Invest. 1996. 97:461-468.) Key words: atherosclerosis • foam cells • RT-PCR • cell isolation - lipid oxidation
\end{abstract}

\section{Introduction}

Macrophage-derived foam cells are one of the hallmarks of the atherosclerotic lesion. Because in vitro studies suggest that macrophages take up native LDL at rates that are insufficient to induce foam cell formation, oxidative modification of LDL has been implicated in foam cell formation and in the pathogenesis of atherosclerosis (1). Oxidation of LDL results in modified LDL that is taken up via the scavenger receptor, present on macrophages (2).

Address correspondence to Dr. O. Wiklund, Wallenberg Laboratory, Sahlgrens Hospital, S-413 45 Göteborg, Sweden. Phone: 46-31602954, FAX: 46-31-823762.

Received for publication 11 November 1994 and accepted in revised form 23 October 1995.

J. Clin. Invest.

(C) The American Society for Clinical Investigation, Inc.

0021-9738/96/01/461/08 \$2.00

Volume 97, Number 2, January 1996, 461-468
One consequence of LDL oxidation is the formation of numerous oxysterols $(3,4)$. Several studies have shown that oxysterols show characteristics that may play a role in atherogenesis, such as inhibition of LDL receptor function in human fibroblasts (5), stimulation of acyl-CoA:cholesterol acyltransferase activity leading to increased formation of cholesterol ester $(6,7)$, and inhibiting the synthesis of prostaglandin $I_{2}$ by endothelial cells leading to enhanced platelet adhesion (8). In addition, oxysterols have also been found to be cytotoxic to endothelial cells and smooth muscle cells in vitro (9-11).

Hodis et al. (12) found that cholesterol feeding in rabbits increased cholesterol oxide levels in plasma and aortic tissue in parallel. The antioxidants probucol and butylated hydroxytoluene $(\mathrm{BHT})^{1}$ inhibit the formation of atherosclerotic lesions and decrease the content of oxysterols in rabbit aorta and in plasma (13-16). Recently, we reported that macrophagederived foam cells isolated from atherosclerotic rabbit aorta contain very high levels of cholesterol ester and cholesterol (17). Hypothetically, if the foam cells have taken up oxidized lipoprotein, some of the cholesterol found in these cells should be oxidized. To our knowledge, occurrence of oxysterols has thus far only been studied in the atherosclerotic aorta in toto, and, with the exception of 27-hydroxycholesterol (18), nothing is known about the presence of oxysterols in isolated arterial macrophages.

In previous studies examining the lipoprotein lipase (LPL) mRNA and enzyme activity in macrophage-derived foam cells isolated from human atherosclerotic aorta, we found that isolated foam cells expressed very low levels of LPL compared with cultured human monocyte-derived macrophages (HMDM) (19). These human aortic foam cells also contained high levels of cholesterol ester and free cholesterol. It is not clear what causes the low expression of LPL in the arterial foam cells. Various aspects of the regulation of LPL synthesis in macrophages have been studied recently (20-23). Lipid loading of macrophages by incubation with chylomicrons, VLDL, and intermediate density lipoprotein is known to suppress LPL secretion up to $70 \%$ (23). In contrast, LPL secretion was enhanced in human monocyte macrophages by incubation with hypertriglyceridemic VLDL (21). Inflammatory macrophages secrete severalfold more LPL than resident cells, whereas LPL secretion in activated macrophages is almost completely turned off $(20,22)$.

The present study was performed to determine if macrophages isolated from atherosclerotic tissue contain oxysterols,

1. Abbreviations used in this paper: BHT, butylated hydroxytoluene; FID, flame ionization detection; HMDM, human monocyte-derived macrophages; LPL, lipoprotein lipase; NZW, New Zealand white; SRE, sterol-regulatory element; WHHL, Watanabe heritable hyperlipidemic. 
and if these oxysterols could mediate a downregulation of LPL mRNA. In view of our previous observations that isolated foam cells expressed very low levels of LPL compared with cultured HMDM (19), it was of interest to determine if oxysterols could mediate downregulation of LPL mRNA in HMDM.

\section{Methods}

Isolation of cells from tissue. Human atherosclerotic tissue samples were obtained from abdominal aorta (subjects 1 and 3) and femoral artery (subject 2) from patients undergoing surgery, because of aortic aneurysm or intermittent claudication. The fresh aortic tissue was immediately placed in a test tube containing HBSS

We used atherosclerotic aortic tissue and plasma from four New Zealand white (NZW) rabbits and from four Watanabe heritable hyperlipidemic (WHHL) rabbits. Atherosclerosis was induced in the NZW rabbits by combining endothelial injury with cholesterol feeding (24). From the day of injury, the rabbits were fed standard rabbit chow supplemented with $1 \%$ cholesterol for $12 \mathrm{wk}$. The WHHL rabbits were fed rabbit chow without additives. Blood samples were collected in tubes containing EDTA and BHT. Human and rabbit aorta were treated the same. The aortic specimens were treated under aseptic conditions, the adventitia was removed, and intima media preparations were used for cell isolation. BHT $0.01 \%$ was added to cell culture media and to PBS to prevent autoxidation. The aortic tissue was digested with collagenase solution as previously described (24), and the isolated cells were suspended in medium RPMI 1640, supplemented with $1 \%$ BSA. The cell suspension was kept on a slurry of ice and water during the isolation and immunomagnetic fractionation.

Macrophages were isolated by using $\mathrm{mAbs}$ and magnetic microspheres as described (17). Briefly, the heterogeneous cell suspension was preincubated with uncoated dynabeads (Dynal AS, Oslo, Norway) for $10 \mathrm{~min}$ to get rid of collagen and elastin fibers. Then the rabbit aortic cells were incubated with rabbit antimacrophage antibody (RAM11), kindly provided by Dr. Allen Gown (University of Washington, Seattle, WA). Human arterial macrophages were isolated by incubation with anti-Leu-M3 (Becton Dickinson \& Co., Sunnyvale, $\mathrm{CA}$ ), detecting the CD14 antigen present on human monocytes/macrophages. The rosetting procedure was carried out by mixing pretreated cells with magnetic beads coated with sheep anti-mouse IgG (Dynal AS). The target cells were then isolated by applying a magnet. Rosetted cells were washed several times with PBS with BHT and inspected for the presence of nonrosetted cells by light microscopy. The rosetted isolated cells were quantitated by counting in a hemocytometer. $\mathrm{CD} 14^{+}$cells were also directly isolated from mononuclear cells from buffy coat by the same procedure that was used for digested cells from tissue. Total foam cell preparation, freshly isolated, was obtained by density gradient centrifugation as described by Rosenfeld et al. (25).

This study was approved by the Ethics Committee and Animal Ethics Committee of Research at the University of Göteborg, Sweden.

Lipid analysis. The macrophages isolated from tissue were divided into two fractions. One fraction was kept in PBS with BHT and stored at $-20^{\circ} \mathrm{C}$ until analysis of oxysterols. The other fraction from tissue macrophages was used to analyze the content of cholesterol ester, triglycerides, and free cholesterol by using TLC combined with flame ionization detection (FID) (26). Lipids were extracted from the cells and from plasma as described by Folch et al. (27) with the addition of BHT, and the sample was applied on a quartz rod coated with silica gel (Chromarod SIII; Newman-Howells Associates Limited, Winchester, UK). Separation of lipids was performed with the use of two sequential solvents: hexane/ethyl ether $(9: 1 \mathrm{vol} / \mathrm{vol})$, hexane/ethyl ether/acetic acid (72:18:1). After each solvent, FID was used to quantify the lipids. The measurements were performed on Iatroscan TH-10 MK2 (Newman-Howells, Winchester, UK), and signals were integrated on a computer (Hewlett-Packard Co., Palo Alto, CA).
Quantification of cholesterol ester and free cholesterol was made by standard comparison.

Oxysterol analysis. Concentrations of oxysterols were determined by isotope dilution mass spectrometry (28). Briefly, $4 \mathrm{ml}$ of ethanol and $0.5 \mathrm{ml}$ of $5-\mathrm{M} \mathrm{NaOH}$ was added to the samples, which were stirred under an argon atmosphere at room temperature for $15 \mathrm{~h}$. Neutralization was accomplished by addition of $2.5 \mathrm{ml}$ of $1-\mathrm{M} \mathrm{HCl}$. The lipids were extracted from the cells with methanol/chloroform $1: 2(\mathrm{vol} / \mathrm{vol})$. After evaporation of the solvent, the samples were dissolved in $0.5 \mathrm{ml}$ chloroform and fractionated (Bond-Elut $\mathrm{NH}_{2}$ column; Varian Sample Preparation Products, Harbor City, CA) as described (29). The neutral lipid fraction was collected, and the solvent was removed under gentle stream of argon and the residue was dissolved in $0.5 \mathrm{ml}$ of methanol/water 9:1 ( $\mathrm{vol} / \mathrm{vol})$. The oxysterols were then analyzed as previously described (28) using deuterated oxysterols as internal standards.

Macrophage cell culture. Mononuclear cells were isolated from buffy coats by the Ficoll-Hypaque procedure (30). HMDM were obtained by culturing mononuclear cells from buffy coat. Mononuclear cells were plated at a density of $10^{7}$ cells per dish. After removal of nonadherent cells, the adhered monocytes were cultured in RPMI 1640 supplemented with $100 \mathrm{U} / \mathrm{ml}$ penicillin, $100 \mu \mathrm{g} / \mathrm{ml}$ streptomycin, $10 \%$ FCS, and $10 \%$ human serum. Every $2 \mathrm{~d}$, the medium was changed. After $7 \mathrm{~d}$, the cells were washed twice with PBS, and oxysterols were added to the cells at a concentration of $5 \mu \mathrm{g} / \mathrm{ml}$ RPMI 1640 medium with $10 \%$ FCS. The sterols, 5 -cholesten-3 $\beta$-ol (cholesterol),

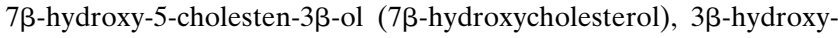

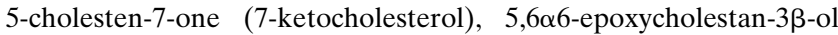

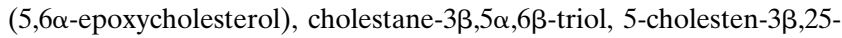
diol (25-hydroxycholesterol) (Sigma Chemical Company, St. Louis, MO), $7 \alpha$-hydroxy-5-cholesten-3 $\beta$-ol ( $7 \alpha$-hydroxycholesterol), 5-cho-

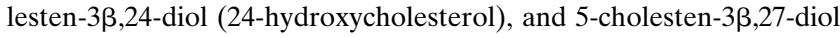
(27-hydroxycholesterol) (Department of Clinical Chemistry, Huddinge Hospital, Huddinge, Sweden), were dissolved in ethanol and added to the culture medium at a final concentration of $0.1 \%$ ethanol. The control incubations were performed in medium containing $0.1 \%$ ethanol. After $24 \mathrm{~h}$, the medium was collected, the cells were washed twice with PBS, and total RNA was isolated. To release LPL to the medium, heparin $10 \mathrm{U} / \mathrm{ml}$ (Löwens, Malmö, Sweden) was added to the cells $30 \mathrm{~min}$ before collecting the medium. The cell viability was evaluated by a dye exclusion test with trypan blue.

Determination of LPL activity. LPL activity released into the medium was determined as previously described (31). In brief, samples of the medium $(5 \mu \mathrm{l})$ were incubated in duplicates in a total volume of $200 \mu \mathrm{l}$ at $25^{\circ} \mathrm{C}$ for $90 \mathrm{~min}$. The substrate was prepared by sonication of $\left[{ }^{3} \mathrm{H}\right]$ triolein (Department of Physiological Chemistry, University of Lund, Sweden) into Intralipid (Kabi Pharmacia, Stockholm, Sweden). The procedure developed by Spooner et al. (32) was used to extract fatty acids for counting. Bovine skim milk was used as a standard to correct for interassay variation. Activity was expressed in milliunits per $10^{6}$ cells. $1 \mathrm{mU}$ corresponds to $1 \mathrm{nmol}$ fatty acids released per min. Control experiments showed that the assay was linear with amount of sample and time over the range used.

Preparation and analysis of RNA. Total cellular RNA was isolated from the HMDM by guanidinium-hydrochloride/isothiocyanate extraction and $\mathrm{CsCl}$ gradient ultracentrifugation (33). The following oligonucleotide primers for LPL were synthesized on a DNA synthesizer (Applied Biosystems, Inc., Foster City, CA): 5'-GAGATTTCTCTGTATGGCACC-3' and 5'-CTGCAAATGAGACACTTTCTC-3'. The $5^{\prime}$ primer spanned the junction of the first two exons, and the $3^{\prime}$ primer spanned the junction of the next two exons for LPL (34). The $5^{\prime}$ primers were labeled in the $5^{\prime}$ end with $\left[\gamma^{-32} \mathrm{P}\right] \mathrm{ATP}$ using polynucleotide kinase. RNA was reverse transcribed into cDNA, and the cDNA was then amplified, together with an internal standard (pAW 109). pAW109 is a synthetic cRNA that contains 5' primers of 12 target mRNAs followed by the complementary sequences of the $3^{\prime}$ primers. Quantitative analysis was performed by PCR as described (19), using Gene Amp RNA PCR kit (Perkin-Elmer Corp., Norwalk, 
CT). Briefly, the reverse transcription mixture in a volume of $20 \mu \mathrm{l}$ containing 1-10 ng total cellular RNA from macrophages, $10^{5}$ molecules of pAW109 cRNA and random hexamer primer was incubated at room temperature for $10 \mathrm{~min}$, at $42^{\circ} \mathrm{C}$ for $15 \mathrm{~min}$, heated to $99^{\circ} \mathrm{C}$ for $5 \mathrm{~min}$, and then incubated at $5^{\circ} \mathrm{C}$ for $5 \mathrm{~min}$. After reverse transcription, serial 1:2 dilutions of the cDNA mixture were amplified by using the $3^{\prime}$ primer together with the ${ }^{32} \mathrm{P}$-labeled 5' primer. The PCR amplification protocol involved denaturation $95^{\circ} \mathrm{C}$ for $1 \mathrm{~min}$, annealing $60^{\circ} \mathrm{C}$ for $1 \mathrm{~min}$ in 35 cycles, and extension $60^{\circ} \mathrm{C}$ for $7 \mathrm{~min}$ for the analysis of mRNA for LPL. All incubations were done in a DNA thermal cycler (Perkin-Elmer Corp.). The PCR products were then separated on a 4\% GTG agarose gel (Nusieve; FMC Bioproducts, Rockland, ME). The electrophoresis was run for $>5 \mathrm{~h}$ and visualized with ethidium bromide (Merck, Darmstadt, Germany). Appropriate bands were cut out from the gel and melted, and the radioactivity was determined by liquid scintillation counting. The amounts of radioactivity recovered from the excised gel bands were plotted against the template concentrations.

\section{Results}

Oxysterol content in arterial macrophages and in plasma. The major oxysterols identified in macrophages isolated from atherosclerotic rabbit aorta were either 7-oxygenated (7-ketocholesterol, 7 $\beta$-hydroxycholesterol and $7 \alpha$-hydroxycholesterol) or 5,6-oxygenated (5,6 $\alpha$ - 5,6 $\beta$-epoxycholesterol and cholestane-3 $\beta, 5 \alpha, 6 \beta$-triol). In addition, smaller amounts of sidechain hydroxylated oxysterols, 24-, 25-, and 27-hydroxycholesterol, were found (Table I). The total amount of oxysterols expressed as nanograms per microgram of cholesterol was found to be between 0.5 and 76 in the arterial foam cells. We have no explanation for the very high oxysterol levels found in rabbit number 4 . In all cases, the 7-oxygenated compounds were found in higher amounts than the 5,6-oxygenated compounds. Cells were also isolated from WHHL rabbit aortas. However, the lesions in WHHL rabbit aortas were small and few in number, and therefore the recovery of macrophagederived foam cells from these rabbits was too low to allow oxysterol analysis.

Fig. 1 shows the distribution of the analyzed oxysterols found in the isolated arterial foam cells. Both rabbit and human cells show about the same distribution of oxysterols except that all three preparations of human arterial-derived

Table I. Oxysterol and Total Cholesterol Content in NZW Rabbit Arterial Macrophage-derived Foam Cells

\begin{tabular}{|c|c|c|c|c|}
\hline Rabbit number & 1 & 2 & 3 & 4 \\
\hline & \multicolumn{4}{|c|}{ ng oxysterol/10 $10^{6}$ macrophages } \\
\hline $7 \alpha$-Hydroxycholesterol & 107 & 242 & 154 & 6,151 \\
\hline 7 $\beta$-Hydroxycholesterol & 179 & 375 & 162 & 13,671 \\
\hline 7-Ketocholesterol & 577 & 1,233 & 973 & 7,355 \\
\hline 5,6 $\alpha$-Epoxycholesterol & 56 & 108 & 464 & 789 \\
\hline 5,6ß-Epoxycholesterol & 252 & 392 & 0 & 5,816 \\
\hline Cholestane- $3 \beta, 5 \alpha, 6 \beta$-triol & 37 & 58 & 0 & 1,138 \\
\hline 24-Hydroxycholesterol & 7 & 0 & 0 & 217 \\
\hline 25-Hydroxycholesterol & 33 & 25 & 0 & 737 \\
\hline 27-Hydroxycholesterol & 0 & 0 & 0 & 434 \\
\hline Total oxysterols (ng) & 1,247 & 2,342 & 1,753 & 36,308 \\
\hline Total cholesterol ( $\mu \mathrm{g})$ & 2,368 & 678 & 744 & 477 \\
\hline Ratio ng oxysterol/ $\mu$ g cholesterol & 0.5 & 3.3 & 2.4 & 76.1 \\
\hline
\end{tabular}

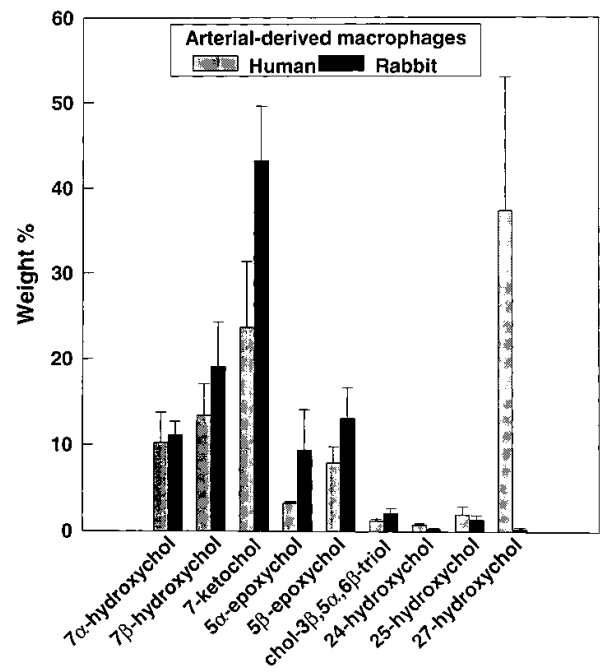

Figure 1. Distribution of cholesterol oxidation products in macrophage-derived foam cells isolated from fresh human atherosclerotic aorta and cholesterol-fed NZW rabbit aorta. CD14 ${ }^{+}$macrophages were isolated by immunomagnetic cell isolation. The lipids were extracted and the oxysterol content was analyzed by gas chromatography-mass spectrometry. Data represent weight percentage of oxysterols analyzed, mean value \pm range from two human aortas and mean value \pm SE from four NZW rabbit aortas.

foam cells contained high levels of 27-hydroxycholesterol, which was not found in rabbit foam cells. Freshly isolated human arterial foam cells from three different subjects, both $\mathrm{CD}_{14}{ }^{+}$and unselected foam cells show a very high content of both cholesterol and oxysterols (Table II). As a comparison, $\mathrm{CD}_{1}{ }^{+}$monocytes, isolated from a healthy volunteer blood donor, contained a total of $192 \mathrm{ng}$ oxysterols $/ 10^{6}$ cells.

Plasma from atherosclerotic rabbits also contained oxysterols. The oxysterols identified in plasma were 7-ketocholesterol, $7 \beta$-hydroxycholesterol, $7 \alpha$-hydroxycholesterol, $5,6 \alpha-5,6 \beta$ epoxycholesterol, cholestane- $3 \beta, 5 \alpha, 6 \beta$-triol, and only trace amounts of 24-, 25-, and 27-hydroxycholesterol. The distribu-

Table II. Oxysterol Content in Human Arterial CD14 Macrophages and from an Unselected Total Foam Cell Preparation Isolated from Atherosclerotic Aorta

\begin{tabular}{|c|c|c|c|}
\hline & $\begin{array}{l}\text { CD14 }{ }^{+} \\
\text {Subject } 1\end{array}$ & $\begin{array}{c}\mathrm{CD}^{4} 4^{+} \\
\text {Subject } 2\end{array}$ & $\begin{array}{c}\text { Total foam } \\
\text { cell preparation } \\
\text { Subject } 3\end{array}$ \\
\hline & \multicolumn{3}{|c|}{ ng oxysterol/10 $0^{6}$ cells } \\
\hline $7 \alpha$-Hydroxycholesterol & 437 & 2,480 & 857 \\
\hline 7 $\beta$-Hydroxycholesterol & 632 & 3,080 & 1,648 \\
\hline 7-Ketocholesterol & 1,031 & 5,660 & 2,773 \\
\hline $5,6 \alpha$-Epoxycholesterol & 203 & 625 & 245 \\
\hline 5,6ß-Epoxycholesterol & 393 & 1,770 & 987 \\
\hline Cholestane- $3 \beta, 5 \alpha, 6 \beta$-triol & 96 & 182 & 367 \\
\hline 24-Hydroxycholesterol & 63 & 108 & 85 \\
\hline 25-Hydroxycholesterol & 191 & 178 & 194 \\
\hline 27-Hydroxycholesterol & 3,440 & 3,935 & 5,586 \\
\hline Total oxysterols (ng) & 6,486 & 18,018 & 12,743 \\
\hline Total cholesterol ( $\mu \mathrm{g})$ & 281 & 563 & 292 \\
\hline Ratio ng oxysterol/ $\mu$ g cholesterol & 23.1 & 32.0 & 43.6 \\
\hline
\end{tabular}




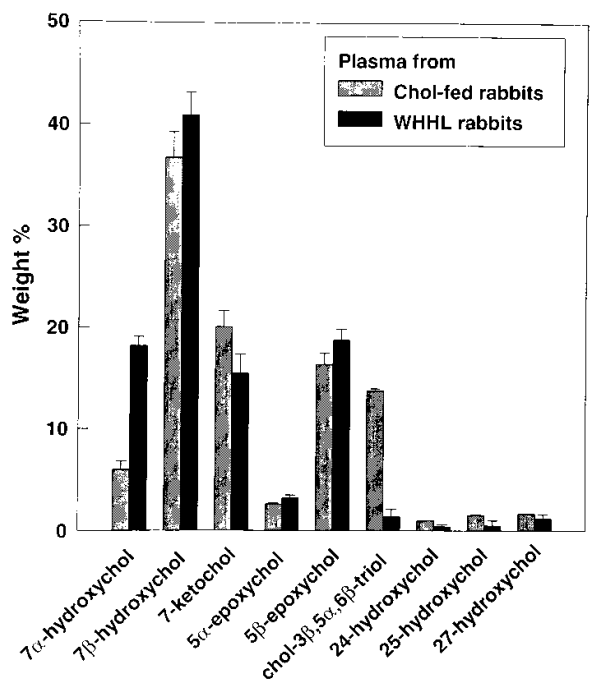

Figure 2. Distribution of cholesterol oxidation products in plasma from cholesterol-fed NZW rabbit and from WHHL rabbits fed with ordinary rabbit chow. Blood was taken in tubes containing EDTA and BHT. The oxysterol content was analyzed in plasma by gas chromatography-mass spectrometry. Data represent weight percentage of oxysterols analyzed, mean \pm range $(n=2)$ for NZW rabbits and mean $\pm \operatorname{SE}(n=4)$ for WHHL rabbits.

tion of the different oxysterols in plasma showed that $\sim 40 \%$ was $7 \beta$-hydroxycholesterol and $\sim 20 \%$ was 7 -ketocholesterol (Fig. 2). When corrected for the cholesterol content, the amount of oxysterols in plasma was $\sim 0.4 \mathrm{ng}$ oxysterol $/ \mu \mathrm{g}$ cholesterol in the cholesterol-fed rabbits $(n=2)$, and $0.3 \mathrm{ng}$ oxysterol $/ \mu \mathrm{g}$ cholesterol in the WHHL rabbits $(n=4)$ (Table III). As shown in Table I, the corresponding figure for arterial cells was in all cases higher than in plasma, suggesting an accumulation of oxysterols in arterial macrophage-derived foam cells.

Regulation of lipoprotein lipase by oxysterols. To determine if oxysterols regulate LPL expression, macrophages were incubated with a series of different oxysterols. As shown in

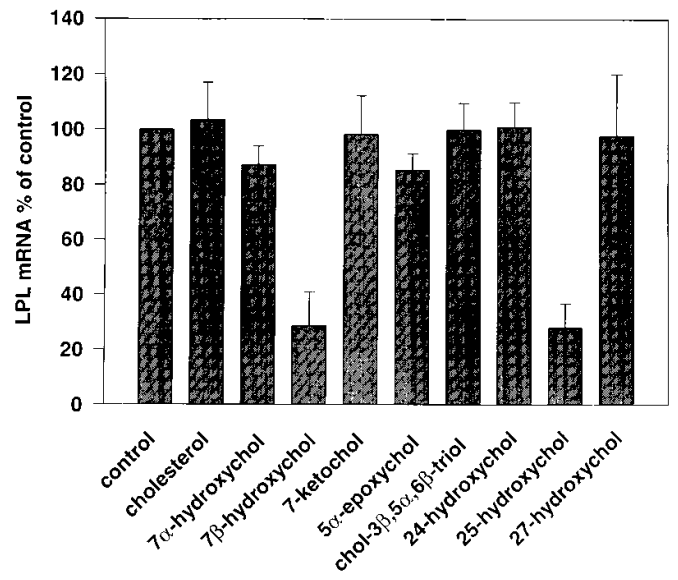

Figure 3. The effect of oxysterols on the LPL mRNA levels in HMDM. 7-d-old HMDM were incubated with oxysterols or cholesterol $(5 \mu \mathrm{g} / \mathrm{ml})$ and without sterols (control) for $24 \mathrm{~h}$. Then the total cellular RNA was extracted and LPL mRNA was quantitated by RTPCR analyses. Values are expressed as percentage of control. Values represent the mean $\pm \mathrm{SE}$ of four different experiments of control, cholesterol, 7 $\beta$-hydroxycholesterol, and 25-hydroxycholesterol, and mean \pm SE of three different experiments of $7 \alpha$-hydroxycholesterol, 7-ketocholesterol, $5,6 \alpha$-epoxycholesterol, cholestane- $3 \beta-5 \alpha-6 \beta$-triol, 24-, and 27-hydroxycholesterol.

Fig. 3, addition of 7 $\beta$-hydroxycholesterol and 25-hydroxycholesterol resulted in a 70-75\% reduction of lipoprotein lipase mRNA at an oxysterol concentration of $5 \mu \mathrm{g} / \mathrm{ml}$ medium compared with controls cultured without oxysterols $(n=4, P<$ 0.01 , Student's $t$-test). There were no significant changes in the LPL mRNA levels after exposure of the macrophages to cholesterol, 7 $\alpha$-hydroxycholesterol, 7-ketocholesterol, 5,6 6 -epoxycholesterol, cholestane-3 $\beta-5 \alpha-6 \beta$-triol, 24-hydroxycholesterol, or 27-hydroxycholesterol, compared with control. The suppressive effect of $7 \beta$-hydroxycholesterol and 25-hydroxycholesterol on LPL mRNA expression was dose dependent (Fig. 4). A $30 \%$ decrease in LPL mRNA was seen after $24 \mathrm{~h}$ incuba-

Table III. Oxysterol and Total Cholesterol Content in Plasma from Cholesterol-fed NZW Rabbits and from WHHL Rabbits

\begin{tabular}{|c|c|c|c|c|c|c|}
\hline \multirow[b]{2}{*}{ Rabbit number } & \multicolumn{2}{|c|}{ NZW rabbits } & \multicolumn{4}{|c|}{ WHHL rabbits } \\
\hline & 3 & 4 & 1 & 2 & 3 & 4 \\
\hline & \multicolumn{6}{|c|}{ ng oxysterol/ml plasma } \\
\hline $7 \alpha$-Hydroxycholesterol & 332 & 371 & 222 & 329 & 263 & 171 \\
\hline $7 \beta$-Hydroxycholesterol & 1,928 & 2,412 & 494 & 588 & 675 & 430 \\
\hline 7-Ketocholesterol & 906 & 1,530 & 266 & 262 & 190 & 120 \\
\hline 5,6 $\alpha$-Epoxycholesterol & 120 & 190 & 29 & 54 & 52 & 35 \\
\hline $5,6 \beta$-Epoxycholesterol & 749 & 1,237 & 210 & 321 & 266 & 206 \\
\hline Cholestane- $3 \beta, 5 \alpha, 6 \beta$-triol & 666 & 990 & 42 & 24 & 0 & 7 \\
\hline 24-Hydroxycholesterol & 48 & 68 & 8 & 0 & 0 & 9 \\
\hline 25-Hydroxycholesterol & 68 & 118 & 26 & 0 & 0 & 0 \\
\hline 27-Hydroxycholesterol & 84 & 121 & 17 & 7 & 10 & 23 \\
\hline Total oxysterols (ng) & 4,901 & 7,037 & 1,314 & 1,585 & 1,456 & 1,001 \\
\hline Total cholesterol $(\mu \mathrm{g})$ & 11,858 & 16,788 & 5,260 & 5,445 & 5,277 & 5,022 \\
\hline Ratio ng oxysterol $/ \mu \mathrm{g}$ cholesterol & 0.4 & 0.4 & 0.3 & 0.3 & 0.3 & 0.2 \\
\hline
\end{tabular}

Oxysterols in plasma from NZW rabbits 1 and 2 were not analyzed, because the tubes in which the blood was taken did not contain BHT. 


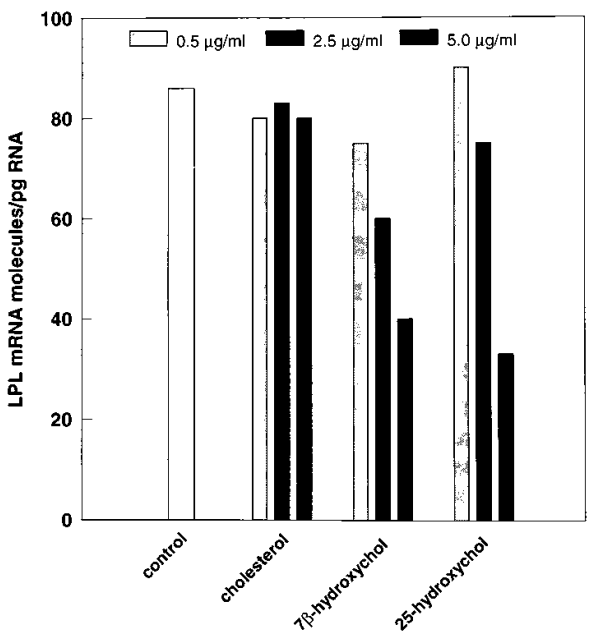

Figure 4. The dose-response effect of oxysterols on the LPL mRNA levels in HMDM. 7-d-old HMDM were incubated with cholesterol, $7 \beta$-hydroxycholesterol, and 25-hydroxycholesterol $(0.5 \mu \mathrm{g} / \mathrm{ml}, 2.5 \mu \mathrm{g} /$ $\mathrm{ml}$, and $5.0 \mu \mathrm{g} / \mathrm{ml}$ ) and without sterols (control) for $24 \mathrm{~h}$. Then the total cellular RNA was extracted, and LPL mRNA was quantitated by RT-PCR.

tion with $2.5 \mu \mathrm{g} / \mathrm{ml}$ of $7 \beta$-hydroxycholesterol, and a $54 \%$ reduction occurred at a concentration of $5.0 \mu \mathrm{g} / \mathrm{ml}$. The LPL mRNA level fell $\sim 13 \%$ in the presence of $2.5 \mu \mathrm{g} 25$-hydroxycholesterol $/ \mathrm{ml}$ medium, and $62 \%$ reduction was seen with 5.0 $\mu \mathrm{g}$ 25-hydroxycholesterol/ml.

Consistent with the observed changes in the level of LPL mRNA, LPL activity in the medium was reduced after exposure of the macrophages to 7 $\beta$-hydroxycholesterol and 25hydroxycholesterol $(n=3)$. In addition cholestane-3 $3,5 \alpha, 6 \beta$ triol and 27-hydroxycholesterol had a significant effect on the activity. The other oxysterols and cholesterol showed minor effects on the levels of LPL activity compared with levels detected in control macrophage cultures (Fig. 5). Since some of the oxysterols have been reported to be toxic to endothelial

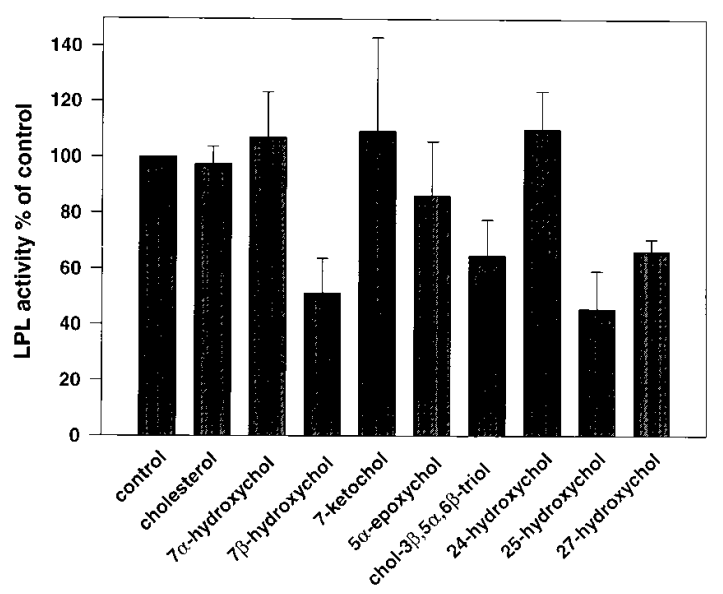

Figure 5. The effect of oxysterols on the LPL activity in the culture media of HMDM. 7-d-old HMDM were incubated with oxysterols and $5 \mu \mathrm{g} / \mathrm{ml}$ cholesterol without sterols (control) for $24 \mathrm{~h} .10 \mathrm{U} / \mathrm{ml}$ heparin was added $30 \mathrm{~min}$ before collecting the media. LPL activity was measured in the medium and is expressed as percentage of control. The data represent the mean values \pm SE of three separate experiments. cells and smooth muscle cells $(9,10)$, HMDM were incubated in one experiment with oxysterols $(5 \mu \mathrm{g} / \mathrm{ml})$ for $24 \mathrm{~h}$, after which the cell viability and isolated RNA per cell were measured. The observed effects were not the result of toxicity to the cells, since the cell viability was in all cases $>98 \%$, and the total amount of RNA isolated per cell was between 4.5 and 5.4 pg for HMDM, irrespective of which oxysterol was used.

To study if the reduction of LPL mRNA by oxysterols was reversible, the induction of LPL by PMA was tested. PMA has been shown to increase LPL in macrophages (24). HMDM were incubated for $24 \mathrm{~h}$ with 25-hydroxycholesterol or $7 \beta$ hydroxycholesterol, PMA (10 nM) was added, and the cells were incubated for a further $24 \mathrm{~h}$. Control cells were incubated for $24 \mathrm{~h}$ with 25-hydroxycholesterol or 7 $\beta$-hydroxycholesterol, and for a further $24 \mathrm{~h}$ without adding PMA. Incubation of HMDM with PMA, in the presence of $7 \beta$-hydroxycholesterol, increased the level of LPL mRNA to 210 molecules/pg RNA as compared with 35 LPL mRNA molecules/pg RNA in the control. The corresponding levels of LPL in HMDM incubated in the presence of 25-hydroxycholesterol were $180 \mathrm{LPL}$ mRNA molecules/pg RNA with PMA and 21 LPL mRNA molecules/pg RNA in the control.

To exclude the possibility that LPL mRNA is suppressed only in CD14-selected macrophages, we have measured oxysterol content and LPL mRNA in a total foam cell preparation. The oxysterol content were similar in CD14-selected cells and in unselected cells. as shown in Table II. The unselected foam cell fraction contained 0.2 LPL mRNA copies/pg RNA. These results are in accordance with the results we have found in CD14-selected foam cells (19).

\section{Discussion}

Macrophage-derived foam cells isolated from human and rabbit atherosclerotic aorta were shown to contain oxidized derivatives of cholesterol. 7-Ketocholesterol was the major oxysterol in macrophages isolated from atherosclerotic tissue, followed by $7 \beta$-hydroxycholesterol and $7 \alpha$-hydroxycholesterol in rabbit cells. Human arterial-derived macrophages contained high levels of 27-hydroxycholesterol not found in rabbit foam cells. The 5,6 $\alpha-, 5,6 \beta$-epoxycholesterol and their hydration product, cholestane- $3 \beta, 5 \alpha, 6 \beta$-triol, were found in both human and rabbit cells. The finding that arterial macrophages contain oxysterols, possibly reflects uptake of oxidized LDL. In vitro studies have shown that HMDM incubated with oxidized LDL, but not with native LDL, have an increased content of 7-ketocholesterol (4). The same study also showed that macrophages themselves could modify LDL, which resulted in the generation of oxysterols. The oxysterols identified in oxidized LDL by other investigators show the same lipid profile as the cellular oxysterols in our study: a high concentration of 7-keto- and 7-hydroxycholesterol $(3,4,35)$. In a recent study, we demonstrated that lipoproteins were taken up by foam cells isolated from rabbit aorta after perfusion with labeled lipoproteins. This uptake of lipoproteins was inhibited by adding vitamin $\mathrm{E}$ to the incubation medium (24). Other evidence that macrophages take up oxidized LDL is provided by Rosenfeld and co-workers. They have shown that arterial wall macrophages contain protein epitopes found in oxidized LDL (25). Taken together, these results suggest that oxidized LDL is taken up by arterial macrophages and can be measured as intracellular accumulation of oxysterols. With the possible ex- 
ception of 27-hydroxycholesterol (18), it is not likely that the oxysterols can be further metabolized in the cells.

The oxysterol levels in plasma were higher in cholesterolfed rabbits than in WHHL rabbits. Earlier, it was believed that the oxysterols could be supplied by LDL, originally arising from autoxidation of cholesterol or from dietary sources (36). However, our results show that oxysterols were present in plasma from both cholesterol-fed rabbits and WHHL rabbits, suggesting that oxysterols could be endogenously produced to some extent. Evidence for in vivo oxidation of cholesterol has been given by Stalenhoef et al. (37). They measured oxysterols in plasma from WHHL rabbits given a cholesterol-free diet. Low doses of probucol could decrease the levels of oxysterols by $50 \%$ (37). In the present study, cholesterol-fed rabbits were found to have 10 times higher levels of cholestane-3 $3,5 \alpha, 6 \beta-$ triol than the WHHL rabbits, indicating a dietary origin of this product. In contrast, $7 \alpha$-hydroxycholesterol was higher in WHHL rabbits than in cholesterol-fed rabbits. High levels of $7 \alpha$-hydroxycholesterol may reflect increased activity of the rate-limiting enzyme in bile acid biosynthesis, the hepatic cholesterol $7 \alpha$-hydroxylase, catalyzing conversion of cholesterol into $7 \alpha$-hydroxycholesterol (38).

Exposure to lipoprotein-bound oxysterols (39) may induce injury to the cells in the vascular wall (40). Particularly, cholestane- $3 \beta, 5 \alpha, 6 \beta$-triol may contribute to inflammation and necrosis (41). Oxysterols may also lead to disruption of the endothelial barrier function $(42,43)$. This loss of barrier function could initiate the early events in atherosclerotic lesion formation, by enhancing monocyte adhesion and infiltration (44). When the oxysterol levels were adjusted for total cholesterol content, the total amount of oxysterol was higher in arterial cells than in plasma, suggesting an accumulation of oxysterols in arterial macrophage-derived foam cells. Formation of the necrotic core may also be increased by cell death due to the toxicity of oxysterols. Taken together, the accumulation of oxysterols in foam cells could mediate toxic and metabolic effects of oxidized LDL on cells in the atherosclerotic lesion.

In previous studies examining the LPL mRNA and activity in $\mathrm{CD}_{14}{ }^{+}$macrophage-derived foam cells isolated from human atherosclerotic aorta, we found that isolated foam cells expressed low levels of LPL (19). This finding is in agreement with our results with an unselected foam cell preparation. Other studies have demonstrated, both by in situ hybridization and by immunohistochemistry, that macrophage foam cells express LPL mRNA in human atherosclerotic tissue (45-47). It is quite possible that the low levels of LPL mRNA we detect in isolated foam cells could also be detected by in situ hybridization. However, compared with cultured HMDM, the tissuederived macrophages contain very low levels of LPL mRNA.

Since oxysterols are biologically active molecules, we investigated the possibility that uptake of oxysterols by the macrophages could explain the low levels of LPL synthesis found in arterial foam cells. We exposed the macrophages to a concentration of oxysterols similar to that found in arterial foam cells. Our results demonstrated suppression of macrophage LPL mRNA and enzyme activity after incubation with $7 \beta-$ hydroxycholesterol and 25-hydroxycholesterol. No effect was seen with cholesterol, $7 \alpha$-hydroxycholesterol, 7-ketocholesterol, $5,6 \alpha$-epoxycholesterol, cholestane-3 $\beta-5 \alpha-6 \beta$-triol, or 24hydroxycholesterol. It has been shown that $7 \beta$-hydroxycholesterol and $7 \beta$-hydroperoxycholesterol, an intermediate to $7 \beta$-hydroxycholesterol, exist in human atherosclerotic lesions
$(48,49)$, and it was observed that fatty streaks show the highest concentration of $7 \beta$-hydroxycholesterol relative to cholesterol (49). Thus, the possibility may exist that the concentrations of oxysterols necessary to downregulate LPL expression in vitro could be present in vivo in advanced lesions. Studies of the effect of oxysterols on LPL in human macrophages have not been reported previously. Since some of the oxysterols have been reported to be toxic to endothelial cells and smooth muscle cells $(9,10)$, the cell viability and isolated RNA per cell were measured. Our results show that, in the concentrations added $(5 \mu \mathrm{g} / \mathrm{ml})$, the oxysterols did not decrease the cell viability or the amount of isolated total RNA in HMDM. Furthermore, the suppressed expression of LPL mRNA by 7 $\beta$-hydroxycholesterol and 25-hydroxycholesterol could be increased by incubation with PMA. Thus, the suppression of LPL mRNA by $7 \beta$-hydroxycholesterol and 25 -hydroxycholesterol is not an effect of decreased cell viability. Although the mechanism of action of oxysterols is not well understood, the existence of cytosolic oxysterol-binding protein suggests that this group of compounds may represent a family of intracellular regulatory factors (50).

It is known that 25-hydroxycholesterol and other oxysterols have the potential to regulate the expression of HMGCoA reductase and LDL receptor genes (51). The promoter regions of these two genes contain a cis-acting element termed the sterol-regulatory element (SRE). The SRE-1 appears to be involved in the negative, coordinate regulation of these genes in response to cellular sterol levels (51). Such a regulatory element could also be found in the $5^{\prime}$ flanking region of the human apo E gene (52). Sequence analysis was performed using the GCG package program (53) on the human LPL gene promoter region up to -1718 bp relative to the transcriptional start site. However, the SRE-1 consensus sequence could not be found in this part of the promoter region of the LPL gene. Thus, other pathways of regulation have to be considered also.

If LPL contributes to foam cell formation in vivo, a regulation of this process by oxysterols may be important. There may be a link between the low LPL synthesis and the oxysterol content in foam cells isolated from atherosclerotic aorta. It is evident that, additional studies will be necessary to determine how oxysterols regulate LPL expression.

In conclusion, we have demonstrated accumulation of oxysterols in macrophage-derived foam cells isolated from atherosclerotic aorta. Our studies suggest that exposure to oxysterols may explain the low levels of LPL mRNA found in these cells. The low expression of LPL in macrophage-derived cells does not support the concept that these cells are a major source of LPL in atherosclerotic tissue. If LPL has any role in foam cell formation, the enzyme probably is derived from other cells, primarily smooth muscle cells, in the lesion. The role of oxysterols as regulators of macrophage function in atherosclerosis has recently been supported in studies from our lab showing that oxysterols may stimulate IL-8 production from macrophages (Liu, Y., L. Mattsson Hultén, and O. Wiklund, manuscript submitted for publication), and, furthermore, some of the oxysterols do downregulate the constitutive expression of the transcription factor AP-1 in macrophages (Ohlsson, B. G., C. Erixon, H. Skribeck, Y. Liu, G. Bondjers, and O. Wiklund, manuscript submitted for publication). Thus, oxysterols may have a central role in the regulation of macrophage function, not only in relation to LPL production, but also for the regulation of cytokine secretion and other cellular functions. 


\section{Acknowledgments}

We thank Birgitta Odén for excellent technical assistance. We wish to express our gratitude to Dr. Knut Pettersson at Astra Hässle AB (Cardiovascular Research Laboratories, Mölndal, Sweden) for providing us with Watanabe heritable hyperlipidemic rabbits.

This study was supported by grants from the Swedish Heart-Lung Foundation (project 41072), Marianne and Marcus Wallenberg Foundation, Stiftelsen Lars Hiertas minne, Tore Nilssons fond för Medicinsk Forskning, Konung Gustaf V:s och Drottning Victorias Stiftelse, and the Medical Research Council (project 4531 and 3041).

\section{References}

1. Steinberg, D., S. Parthasarathy, T. E. Carew, J. C. Khoo, and J. L. Witztum. 1989. Beyond cholesterol: modifications of low-density lipoprotein that increase its atherogenicity. N. Engl. J. Med. 14:915-924.

2. Brown, M. S., and J. L. Goldstein. 1983. Lipoprotein metabolism in the macrophage: implications for cholesterol deposition in atherosclerosis. Апnи. Rev. Biochem. 52:223-261.

3. Zhang, H., H. J. K. Basra, and U. P. Steinbrecher. 1990. Effects of oxidatively modified LDL on cholesterol esterification in cultured macrophages. $J$. Lipid Res. 31:1361-1369.

4. Jialal, I., D. A. Freeman, and S. M. Grundy. 1991. Varying susceptibility of different low density lipoproteins to oxidative modification. Arterioscler. Thromb. 11:482-488.

5. Brown, M. S., and J. L. Goldstein. 1975. Regulation of the activity of the low density lipoprotein receptor in human fibroblasts. Cell. 6:307-316.

6. Brown, M. S., S. E. Dana, and J. L. Goldstein. 1975. Cholesterol ester formation in cultured human fibroblasts: stimulation by oxygenated sterols. $J$. Biol. Chem. 250:4025-4027.

7. Morin, R. J., and S. Peng. 1989. Effects of cholesterol oxidation derivatives on cholesterol esterifying and cholesterol ester hydrolytic enzyme activity of cultured rabbit aortic smooth muscle cells. Lipids. 24:217-220.

8. Hu, B., S. Peng, D. Brubaker, and R. J. Morin. 1990. Influence of cholesterol oxides and antioxidants on prostacyclin production by cultured endothelial cells. FASEB J. 4:A267, Abstr. No. 3734.

9. Pettersen, K. S., K. M. Boberg, A. Stabursvik, and H. Prydz. 1991. Toxicity of oxygenated cholesterol derivatives toward cultured human umbilical vein endothelial cells. Arterioscler. Thromb. 11:423-428.

10. Sevanian, A., J. Berliner, and H. Peterson. 1991. Uptake, metabolism, and cytotoxicity of isomeric cholesterol-5,6-epoxides in rabbit aortic endothelial cells. J. Lipid Res. 32:147-155.

11. Zhou, Q., T. L. Smith, and F. A. Kummerow. 1993. Cytotoxicity of oxysterols on cultured smooth muscle cells from human umbilical arteries. Proc. Soc. Exp. Biol. Med. 202:75-80.

12. Hodis, H. N., D. W. Crawford, and A. Sevanian. 1991. Cholesterol feeding increases plasma and aortic tissue cholesterol oxide levels in parallel: further evidence for the role of cholesterol oxidation in atherosclerosis. Atherosclerosis. 89:117-126.

13. Carew, T. E., D. C. Schwenke, and D. Steinberg. 1987. An antiatherogenic effect of probucol unrelated to its hypercholesterolemic effect; evidence that antioxidants in vivo can selectively inhibit low density degradation in macrophage-rich fatty streaks slowing the progression of atherosclerosis in the WHHL rabbit. Proc. Natl. Acad. Sci. USA. 84:7725-7729.

14. Björkhem, I., A. Henriksson-Freyschuss, O. Breuer, U. Diczfalusy, L. Berglund, and P. Henriksson 1991. The antioxidant butylated hydroxytoluene protects against atherosclerosis. Arterioscler. Thromb. 11:15-22.

15. Freyschuss, A., A. Stiko-Ram, J. Swedenborg, P. Henriksson, I. Björkhem, L. Berglund, and J. Nilsson. 1993. Antioxidant treatment inhibits the development of intimal thickening after balloon injury of the aorta in hypercholesterolemic rabbits. J. Clin. Invest. 91:1282-1288.

16. Hodis, H. N., A. Chauhan, S. Hashimoto, D. W. Crawford, and A. Sevanian. 1992. Probucol reduces plasma and aortic wall oxysterol levels in cholesterol fed rabbits independently of its plasma cholesterol lowering effects. Atherosclerosis. 96:125-134.

17. Mattsson, L., G. Bondjers, and O. Wiklund. 1991. Isolation of cell populations from arterial tissue, using monoclonal antibodies and magnetic microspheres. Atherosclerosis. 89:25-34.

18. Björkhem, I., O. Andersson, U. Diczfalusy, B. Sevastik, R.-J. Xiu, C. Duan, and E. Lund. 1994. Atherosclerosis and sterol 27-hydroxylase: evidence for a role of this enzyme in elimination of cholesterol from human macrophages. Proc. Natl. Acad. Sci. USA. 91:8592-8596.

19. Mattsson, L., H. Johansson, M. Ottosson, G. Bondjers, and O. Wiklund. 1993. Expression of lipoprotein lipase mRNA and secretion in macrophages isolated from human atherosclerotic aorta. J. Clin. Invest. 92:1759-1765.

20. Behr, S. R., and F. B. Kraemer. 1986. Effects of activation on lipoprotein lipase secretion by macrophages: evidence for autoregulation. J. Exp. Med. 164:1362-1367.
21. Ishibashi, S., N. Mori, T. Murase, H. Shimano, T. Gotohda, M. Kawakami, Y. Akanuma, F. Takaku, and N. Yamada. 1989. Enhanced lipoprotein lipase secretion from human monocyte-derived macrophages caused by hypertriglyceridemic very low density lipoproteins. Arteriosclerosis. 9:650-655.

22. Sofer, O., and R. Goldman. 1987. Bacterial lipopolysaccaride suppresses the expression of lipoprotein lipase in murine macrophages: a process independent of tumor necrosis factor or interleukin 1. Immunol. Lett. 15:261-265.

23. Sofer, O., M. Fainaru, Z. Schafer, and R. Goldman. 1992. Regulation of lipoprotein lipase secretion in murine macrophages during foam cell formation in vitro. Arterioscler. Thromb. 12:1458-1466.

24. Wiklund, O., L. Mattsson, T. Björnheden, C. Camejo, and G. Bondjers. 1991. Uptake and degradation of low density lipoproteins in atherosclerotic rabbit aorta: the role of local modification. J. Lipid Res. 32:55-62.

25. Rosenfeld, M. E., J. C. Khoo, E. Miller, S. Parthasarathy, W. Palinski, and J. L. Witztum. 1991. Macrophage-derived foam cells freshly isolated from rabbit atherosclerotic lesions degrade modified lipoproteins, promote oxidation of low density lipoproteins, and contain oxidation-specific lipid-protein adducts. J. Clin. Invest. 87:90-99.

26. Bondjers, G., T. Linden, G. Fager, S.-O. Olofsson, G. Olsson, and O. Wiklund. 1988. Aortic intimal lipid content and serum lipoproteins in patients undergoing coronary by-pass surgery as related to clinical prognosis. Atherosclerosis. 72:231-239.

27. Folch, J., M. Lees, and G. H. A. Sloane-Stanley. 1960. A simple method for the isolation and purification of total lipids from animal tissues. J. Biol. Chem. 226:497-509.

28. Breuer, O., and I. Björkhem. 1990. Simultaneous quantification of several cholesterol autoxidation and monohydroxylation products by isotope-dilution mass spectrometry. Steroids. 55:185-192.

29. Kaluzny, M. A., L. A. Duncan, M. V. Merritt, and D. E. Epps. 1985. Rapid separation of lipid classes in high yield and purity using bonded phase columns. J. Lipid Res. 26:135-140.

30. Böyum, A. 1976. Isolation of lymphocytes, granulocytes and macrophages. Scand. J. Immunol. 5(Suppl. 5):9-15.

31. Bengtsson-Olivecrona, G., and T. Olivecrona. 1992. Assay of lipoprotein lipase and hepatic lipase. In Lipoprotein Analyses: A Practical Approach. C. A. Converse and E. R. Skinner, editors. Oxford University Press, Oxford. 169-185.

32. Spooner, P. M., M. M. Garrison, and R. O. Scow. 1977. Regulation of mammary and adipose tissue lipoprotein lipase and blood triacylglycerol in rats during late pregnancy. J. Clin. Invest. 60:702-708.

33. Chirgwin, J. M., A. M. Przybyla, R. J. MacDonald, and W. J. Rutter. 1979. Isolation of biologically active ribonucleic acid from sources enriched in ribonuclease. Biochemistry. 18:5294-5298.

34. Wion, K. L., T. G. Kirchgessner, A. J. Lusis, M. C. Schotz, and R. M. Lawn. 1987. Human lipoprotein lipase complementary DNA sequence. Science (Wash. DC). 235:1638-1641.

35. Bhadra, S., M. A. Q. Arshad, Z. Rymaszewski, E. Norman, R. Wherley, and M. T. R. Subbiah. 1991. Oxidation of cholesterol moiety of low density lipoprotein in the presence of human endothelial cells or $\mathrm{Cu}^{2+}$ ions: identification of major products and their effects. Biochem. Biophys. Res. Commun. 176: 431-440.

36. Schroepfer, G. J., Jr. 1981. Sterol biosynthesis. Annu. Rev. Biochem. 50: 585-621.

37. Stalenhoef, A. F. H., H. A. Kleinveld, T. G. Kosmeijer-Schuil, P. N. M. Dermacker, and M. B. Katan. 1993. In vivo oxidised cholesterol in atherosclerosis. Atherosclerosis. 98:113-114.

38. Björkhem, I., E. Reihnér, B. Angelin, S. Ewerth, J-E. Åkerlund, and K. Einarsson. 1987. On the possible use of the serum level of $7 \alpha$-hydroxycholesterol as a marker for increased activity of the cholesterol $7 \alpha$-hydroxylase in humans. J. Lipid Res. 28:889-894.

39. Peng, S., G. A. Phillips, G.-Z. Xia, and R. J. Morin. 1987. Transport of cholesterol autoxidation products in rabbit lipoproteins. Atherosclerosis. 64:1-6.

40. Peng, S., C. B. Taylor, J. C. Hill, and R. J. Morin. 1985. Cholesterol oxidation derivatives and arterial endothelial damage. Atherosclerosis. 54:121-133.

41. Baranowski, A., C. W. M. Adams, O. B. Bayliss-High, and D. B. Bowyer. 1982. Connective tissue responses to oxysterols. Atherosclerosis. 41:255266.

42. Boissonneault, G. A., B. Hennig, and C.-M. Ouyang. 1991. Oxysterols, cholesterol biosynthesis, and vascular endothelial cell monolayer barrier function. Proc. Soc. Exp. Biol. Med. 196:338-343.

43. Hennig, B., and G. A. Boissonneault. 1987. Cholestane- $3 \beta-5 \alpha-6 \beta$-triol decreases barrier function of cultured endothelial cell monolayers. Atherosclerosis. 68:255-261.

44. Berliner, J. A., M. C. Territo, A. Sevanian, S. Ramin, J. A. Kim, B. Bamshad, M. Esterson, and A. M. Fogelman. 1990. Minimally modified low density lipoprotein stimulates monocyte endothelial interactions. J. Clin. Invest. 85:1260-1266.

45. Ylä-Herttuala, S., B. A. Lipton, M. E. Rosenfeld, I. J. Goldberg, D. Steinberg, and J. L. Witztum. 1991. Macrophages and smooth muscle cells express lipoprotein lipase in human and rabbit atherosclerotic lesions. Proc. Natl. Acad. Sci. USA. 88:10143-10147.

46. O'Brien, K. D., D. Gordon, S. Deeb, M. Ferguson, and A. Chait. 1992. Lipoprotein lipase is synthesized by macrophage-derived foam cells in human 
coronary atherosclerotic plaques. J. Clin. Invest. 89:1544-1550.

47. O'Brien, K. D., S. S. Deeb, M. Ferguson, T. O. McDonald, M. D. Allen, C. E. Alpers, and A. Chait. 1994. Apolipoprotein E localization in human coronary atherosclerotic plaques by in situ hybrization and immunohistochemistry and comparison with lipoprotein lipase. Am. J. Pathol. 144:538-548.

48. Chisolm, G. M., G. Ma, K. C. Irwin, L. L. Martin, K. M. Gunderson, L. F. Linberg, D. W. Morel, and P. E. DiCorleto. 1994. 7 $\beta$-Hydroperoxycholest5-en-3 $\beta$-ol, a component of human atherosclerotic lesions, is the primary cytotoxin of oxidized human low density lipoprotein. Proc. Natl. Acad. Sci. USA. 91: $11452-11456$.

49. Carpenter K. L. H., S. E. Taylor, C. van der Veen, B. K. Williamson, J. B. Ballantine, and M. J. Mitchinson. 1995. Lipids and oxidised lipids in human atherosclerotic lesions at different stages of development. Biochim. Bio- phys. Acta. 1256:141-150.

50. Ridgway, N. D., P. A. Dawson, Y. K. Ho, M. S. Brown, and J. L. Goldstein. 1992. Translocation of oxysterol binding protein to Golgi apparatus triggered by ligand binding. J. Cell Biol. 116:307-319.

51. Goldstein, J. L., and M. S. Brown. 1990. Regulation of the mevalonate pathway. Nature (Lond.). 343:425-430.

52. Paik, Y.-K., D. J. Chang, C. A. Reardon, M. D. Walker, E. Taxman, and J. M. Taylor. 1988. Identification and characterization of transcriptional regulatory regions associated with expression of the human apolipoprotein E gene. $J$. Biol. Chem. 263:13340-13349.

53. Devereux, J., P. Haeberli, and O. Smithies. 1984. A comprehensive set of sequence analysis programs for the VAX. Nucleic Acids Res. 12:387-395. 